\title{
EXPLORING CHARACTER COMPLEXITIES AND STORYTELLING STYLE OF AMAZON PRIME'S WEB SERIES MADE IN HEAVEN: DEPICTION OF CULTURAL AND SOCIAL STIGMAS THROUGH BIG FAT INDIAN WEDDINGS
}

\author{
SHIVANSHU PATHAK \& ALISHAH SYEDAIN
}

Assistant Professor, Amity School of Communication, Amity University, AUUP, Lucknow, India

Over the top platforms are leading the new media market today. People are watching content on smartphones and other devices with the principle concept of going solo.Accessibility of content on a single click and the privacy to watch desired content has given rise to the over the top platforms rapidly in the past five years. Online streaming has popularised a new genre of content-driven web series amongst viewers. The 'on the go" nature of web series gives the flexibility to access web episodes at ease.

This main objective of this study is to explore the narrative and story development style of a very popular Amazon Prime's web series Made in Heaven, released in 2019. The very popular series depicts social issues and stigmas in contemporary way. The show highlights conservative mindsets of supposedly liberal societies in a quintessential narrative.

The study aims to understand the different character journeys and relationship graphs as the season proceeds. The study will also analyze the viewers perspectives on the content of Made in Heaven.

The methodology adopted for the research is the analysis of the content of Amazon Prime's Made in Heaven (2019) indepth with each episode of the season. The researcher would also incorporate a survey with the viewers of the series to understand their opinions. Based on the responses, a narrative and story progression graph of Made in Heaven is discussed
\end{abstract}

KEYWORDS: Over the Top platform, Web series, Amazon Prime, Made in Heaven \& Zoya Akhtar

Received: Apr 23, 2020; Accepted: May 13, 2020; Published: Jul 13, 2020; Paper Id.: IJMPERDJUN2020298

\section{INTRODUCTION}

India is the fastest-growing entertainment and media market globally. In the last 5 years, there has been a significant rise in the OTT (Over the Top) media services which offer direct video streaming services to viewers. The concept is driven form video on demand and has attracted viewers tremendously. The Net Neutrality has paved the path to welcome International and domestic online streaming platforms in the market. Through an enhanced distribution network, these platforms forayed into untapped territories and languages leading to a resounding rise in viewership. Of course, the same also must be credited to the Indian Government's initiative of 'Digitisation', and 'Jiofication' of the country. As of January 2018, 430.3 million users accessed the internet through mobile devices, 93 percent of the total number of internet subscribers in India (EY \& FCCI, 2018). Technological disruption has altered consumption patterns, and an improvement in internet penetration has re-branded India's digital revolution in entertainment.(Singh, 2019)

As per the report published by Telecom Regulatory Authority of India on 3rd Oct 2018, the number of Internet subscribers in June 2018 is 512.26 million showing a 3.7\% increase from that of March 2018. Out of the 
512.26 million internet subscriber base, $66.15 \%$ are from urban areas and the remaining 33.85\% are from rural areas.(Grover \& Kadam, 2019)

\section{What is OTT(Over the top) platform?}

OTT is simply the delivery of video and audio content, via the internet directly to the user(s) connected devices. It allows access to services anywhere anytime and on any device. Consumers are now getting access to on-demand content on these OTT platforms alongside traditional linear content. Many professionals have predicted OTT platforms to be the future of this industry. (Mark Hooper, 2010)

In 2018, the OTT industry was valued at Rs. 21.5B. In 2019, its value has reached Rs. 35B. It is showing signs of growth typical of a young industry about to explode onto the scene.

According to a recent report by $\mathrm{PwC}$, the OTT market is set to grow at a rate of $22 \%$ to reach Rs 12,000 crore in the next four years. The soon-to-arrive 5G networks will only work as a shot in the arm for OTT platforms.(Khatri, 2020)

Netflix, Amazon Prime Video, Hotstar, Zee5, ALTBalaji, MX Player, and Voot are the popular OTT platforms that provide easy access to movies, television shows, documentaries, and web series from all over the world.(Moochhala, 2018) These platforms are producing 'original shows', 'original movies' along with streaming popular movies, classics and prominent television shows like Game of Thrones, Friends, Big Bang Theory, Crown, Grey's Anatomy, Money Heist, Arcos and others. (See Netflix) (See Amazon Prime Video) \&(Hotstar). This gives ease, quality content and accessibility to global content to viewers worldwide.

Action, Romance, Sitcoms, Thrillers, horror, historical and drama are the preferred genres of web series. Sitcom, Drama and Thrillers lead the online streaming platforms.(Barra, 2009)

Online streaming apps enjoy a distinct advantage over any other mainstream entertainment platform. Unlike a typical television channel or a movie theatre, online streaming apps allow the viewer to choose and decide what, where and when to watch the videos they like irrespective of the barriers of time, space and location(Das, 2020)

These platforms are streaming popular TV web series of Hollywood and world cinema along with producing original shows. The web series is the most popular genre of online streaming apps providing a plethora of options to viewers worldwide. (Singh, 2019)

The inclination towards web series has been observed across all age groups. Internet users have happily switched their interest from television episodes to web episodes. The fact that web series do not have censorship, limited episodes, producers, and directors have a blanket of creative liberty to create impactful content. Based on the demand of the show and the response by the viewers, content creators extend seasons to proceed the storylines.(Grover \& Kadam, 2019)(Bucaria)

Amazon Prime Video is an American OTT platform owned by Amazon Pvt Ltd. The prime video was launched in India in 2016 and is currently the second most popular video streaming service after Hotstar. Amazon Prime Video has given platform to many original Indian fictional television web series like Family man, Inside Edge, four more shots please, and Made in Heaven.

The interesting point is that prominent directors and writers are showing interest in web content. Many directors like Anurag Kashyap, Ekta Kapoor, and Zoya Akhtar are directing and producing web series on these platforms. 
The researcher will study the storytelling style and character complexities and relationship dynamics of a 2019 Amazon Prime's web series Made in Heaven, Season 1 in complete depth.

\section{Made in Heaven- Literature Review}

Made in Heaven was released on Amazon Prime on $8^{\text {th }}$ March 2019. The show has an IMDb rating of 8.3/10 and has received positive reviews from renowned film critics.(IMDb, 2019)

The show Made in Heaven is an original web series of Amazon Prime Video produced by Excel Entertainment, owned by Farhan Akhtar and Ritesh Sidhwani. Prominent Hindi film director, Zoya Akhtar and Reema Kagti are the creators of the show. Akhtar and Kagti have collaborated for several mainstream film projects together. The creators of the show arepopular personalities with a series of credible work lineage:

Table 1.1

\begin{tabular}{|l|l|l|l|}
\hline Creators & $\begin{array}{l}\text { Role in Made In } \\
\text { Heaven Season 1 }\end{array}$ & $\begin{array}{l}\text { Prominent works: } \\
\text { Directorial }\end{array}$ & $\begin{array}{l}\text { Prominent } \\
\text { works: Writer }\end{array}$ \\
\hline Zoya Akhtar & Writer-Director & $\begin{array}{l}\text { Luck by Chance, Zindagi na } \\
\text { Milegi Dobara, Dil Dhadakne } \\
\text { Do, Gully Boy }\end{array}$ & $\begin{array}{l}\text { Talaash, Gully } \\
\text { Boy }\end{array}$ \\
\hline Reema Kagti & Writer & $\begin{array}{l}\text { Honeymoon Travels Pvt. } \\
\text { Ltd, Talaash, Gold }\end{array}$ & Gully Boy \\
\hline Alankrita Shrivastava & Writer- Director & $\begin{array}{l}\text { Turning 30, Lipstick under } \\
\text { my Burkha }\end{array}$ & $\begin{array}{l}\text { Lipstick under my } \\
\text { Burkha }\end{array}$ \\
\hline Nitya Mishra & Director & $\begin{array}{l}\text { Assistant director in Life of } \\
\text { Pi, Namesake, Relutant } \\
\text { Fundamentalist }\end{array}$ & \\
\hline Prashant Nair & Director & Umrika & \\
\hline
\end{tabular}

Made in Heaven (2019) is a fictional television web series based in Delhi. The plot of the story revolves around life chronicles of two protagonists Tara and Karan, who together run a high-profile wedding planning company in Delhi named "Made in Heaven". The web series intricately deals with social and cultural stigmas under the blanket of big fat Indian weddings. The supposedly liberal fabric of upper crust unravels as the duo navigates through arranged marriages. The web series has released one season with nine episodes in 2019. Each episode is focussing on a different issue highlighting the relationship and cultural nuances through the weddings.(IMDb, 2019)(https://www.youtube.com/, 2019) 
Table 1.2

\begin{tabular}{|c|c|c|c|c|c|c|c|}
\hline \begin{tabular}{|l|} 
Season 1 \\
Episode \\
\end{tabular} & $\begin{array}{l}\text { Name of } \\
\text { Episode }\end{array}$ & Writer & Director & $\begin{array}{l}\text { Season } 1 \\
\text { Episode }\end{array}$ & $\begin{array}{l}\text { Name of } \\
\text { Episode }\end{array}$ & Writer & Director \\
\hline 1 & $\begin{array}{l}\text { "All That } \\
\text { Glitters Is } \\
\text { Gold" }\end{array}$ & \begin{tabular}{|l} 
Alankrita \\
Shrivastava, \\
Zoya Akhtar, \\
Reema Kagti
\end{tabular} & $\begin{array}{l}\text { Zoya } \\
\text { Akhtar }\end{array}$ & 6 & $\begin{array}{l}\text { "Something } \\
\text { Old, } \\
\text { Something } \\
\text { New" }\end{array}$ & \begin{tabular}{|l} 
Alankrita \\
Shrivastava, \\
Zoya Akhtar, \\
Reema Kagti
\end{tabular} & Prashant Nair \\
\hline 2 & $\begin{array}{l}\text { "Star Struck } \\
\text { Lovers" }\end{array}$ & \begin{tabular}{|l} 
Alankrita \\
Shrivastava, \\
Zoya Akhtar, \\
Reema Kagti
\end{tabular} & $\begin{array}{l}\text { Zoya } \\
\text { Akhtar }\end{array}$ & 7 & $\begin{array}{l}\text { "A Royal } \\
\text { Affair" }\end{array}$ & \begin{tabular}{|l} 
Alankrita \\
Shrivastava, \\
Zoya Akhtar, \\
Reema Kagti
\end{tabular} & Nitya Mishra \\
\hline 3 & $\begin{array}{l}\text { "It's Never } \\
\text { Too Late" }\end{array}$ & \begin{tabular}{|l} 
Alankrita \\
Shrivastava, \\
Zoya Akhtar, \\
Reema Kagti
\end{tabular} & $\begin{array}{l}\text { Nitya } \\
\text { Mishra }\end{array}$ & 8 & $\begin{array}{l}\text { "Pride and } \\
\text { Bridezilla" }\end{array}$ & \begin{tabular}{|l} 
Alankrita \\
Shrivastava, \\
Zoya Akhtar, \\
Reema Kagti
\end{tabular} & $\begin{array}{l}\text { Alankrita } \\
\text { Shrivastava }\end{array}$ \\
\hline 4 & $\begin{array}{l}\text { "The Price of } \\
\text { Love" }\end{array}$ & \begin{tabular}{|l} 
Alankrita \\
Shrivastava, \\
Zoya Akhtar, \\
Reema Kagti
\end{tabular} & $\begin{array}{l}\text { Nitya } \\
\text { Mishra }\end{array}$ & 9 & $\begin{array}{l}\text { "The Great } \\
\text { Escape" }\end{array}$ & \begin{tabular}{|l} 
Alankrita \\
Shrivastava, \\
Zoya Akhtar, \\
Reema Kagti
\end{tabular} & $\begin{array}{l}\text { Alankrita } \\
\text { Shrivastava }\end{array}$ \\
\hline 5 & $\begin{array}{l}\text { "A Marriage } \\
\text { of } \\
\text { Convenience }\end{array}$ & $\begin{array}{l}\text { Alankrita } \\
\text { Shrivastava, } \\
\text { Zoya Akhtar, }\end{array}$ & $\begin{array}{l}\text { Prashant } \\
\text { Nair }\end{array}$ & & & & \\
\hline
\end{tabular}

“ALWAYS FIND A UNIQUE STORY.100 YEARS OF CINEMA HAS HAPPENED. DON'T GIVE AUDIENCE THE SAME CRAP"

\section{RAJKUMAR HIRANI}

Watching television series has become the national pastime for an internet user between age group 18-45. Relationships love, compassion, commitment, dirty secrets of big fat Indian weddings, Amazon Prime's latest Indian original follows the story of two wedding planners in Delhi. Through their scheming, lying, and, at times, brave and selfless ways, they help join the rich and affluent South Delhi types and their princesses, in holy matrimony.

These two -- and the brides and grooms they are serving -- often lie to get their way. But like most of us who also lie, cheat, or deceive to get by in life, they too do not always get their comeuppance and guilty consciences do not always find closure. Again, much like real life.

Made In Heaven presents the seemingly perfect face of rich Delhi wedding scene, but look beneath the gold and glitter and it is all dauntingly dark. Parents are looking for pure and pious brides for their sons, men organizing beauty pageants to search for brides, brides building their marriages on lies and marriages being bought in exchange for builder flats. Everyone is out to score the biggest score, love is damned, justice is damned, and self-respect is damned.

In Made In Heaven story keeps on going back and forth (flashback and present) to reveal the complexities and background of main characters (Tara and Karan) from time to time through the marriages that they organize and their personal and professional journeys with Made In Heaven. It is not about pitch-perfect love, perfect family, perfect relationship, etc. It is about grey people who live the grey, who walk the grey, who surround themselves with grey grassroot grey, the script allows for grey which is the richest color in cinema.

The nine episodes are told as an anthology with the planners facing a new, peculiar couple and their parents every 
time. Meanwhile, the protagonists, Tara and Karan, and their struggles with a failing marriage and closeted sexuality make for the thread on which the 9 stories are beaded.

There is a lot more time to delve deeply into the characters. One gets a chance to unravel them. Also, one can focus on other characters as well and present their personal stories. Not all characters belong to the same social strata in the series. Made in Heaven is a very democratic show. Marriages are a popular theme and celebrating Indian weddings. It's funny and dramatic. It deals with social and personal issues. Overall, it's a mixed bag. It is based in India that is on the cusp of modernity but is even looking back towards tradition. It has all the ingredients for a delicious drama. Chaos in the family. There is no wedding without tension in the family. There are no perfect circumstances.

\section{Sketches about Social \& Cultural Stigma Through Weddings}

\section{Episode-1}

\section{"All that glitters is gold."}

Roshans plan a sting operation to Alia, would be daughter in law and came to know that she had an abortion 4 years ago. Their son knows about that and has no problem.

Tara and Karan suggest the groom to tell his parents that the child was his. Knowing this now Roshans agreed for marriage. Alia gets annoyed but 5000 crore gets Alia hooked as Tara suggested Alia- "Eventually they (you're in-laws) are going to die babe and all the money is yours." Five thousand crore.

"All that glitters is gold" Questions the narrow thinking of very poor super rich peoples in terms of values. If a girl gets pregnant and had an abortion before the marriage one can question the girl's value system and can't accept her as their daughter in law. But if their son says that she was pregnant with his child everything becomes hunky-dory and acceptable.

\section{Episode-2}

\section{"Starstruck lovers"}

Harsimran (bride to be)wants to invite Sarfaraz Knan (a film star) at one of the wedding events. Sarfaraz comes through Made in Heaven. Harsimran sleeps with Sarfaraz. Her lip-to-lip pic goes viral on social media. Joginder (the groom to be) goes mad to kill Sarfaraz with hockey in the hotel which is owned by his family. Aftermath Khan locks himself in his hotel room. Joginder's parents eventually step in to defuse the situation. Tara and Karan then find out that Harsimran also slept with Khan that night. However, they manage to delete the footage from the hotel cameras before anyone else can find out. Jazz gets into trouble for sharing pictures from the wedding on her Facebook page. But she makes up for it by helping Joginder and Harsimran make up. Tara convinces Harsimran to pray at Joginder's gurudwara and cook prasad for him and let the secret be secret and be happy. They eventually reconcile and the wedding goes off without a hitch.

"Starstruck lovers" questions the transparency of a relationship. It focuses on the greyness of a relationship like is it okay to start a relationship with a lie and keep few secrets unshared to start afresh.

\section{Episode-3}

\section{"Its never too late"}

Gayatri Mathur is a widow in sixties falls in love with a Bengali architect Bijoy Chatterjee.It is fantastic and pure union in which everybody is happy accept Gayatri's children which matters her the most.Made In Heaven organize their wedding. 
Gayatri's children refuse to attend the wedding. Many a time Karan and Tara go outside their jurisdiction as service providers or just as a wedding planner and succumb to human nature..Karan goes to convince Gayatri's daughter and fakes about his mother's death that she died lonely after his father divorced his mother. This trick works and both her children come for Gayatri's wedding. -happy for their mother.

"Its never too late" questions the acceptance of an old mother getting married whose children are married as the children are not there for their mother getting married at this age Gayatri's daughter says that my mom doesn't need to get married.She can meet that person in private if she wants to but marriage is out of question raises many questions.

\section{Episode-4}

\section{The price of Love-}

Karan and Tara plan the wedding of an IAS officer Vishal and his fiancé Priyanka who are funding their wedding themselves. On the day of the wedding, Vishal's parents who seems to be modern and progressive suddenly demand a huge cash or a flat as a dowry and threaten to cancel the wedding if refused. Priyanka's father reluctantly agrees but asks Tara and Karan to keep this hidden from Priyanka. Tara agrees but later on tells everything to Priyanka just before the wedding nuptials. start. Priyanka argues with Vishal and comes to know that he agreed to the whole plan. Now she takes the brave step and calls off the wedding..

"The price of Love" portrays the hypocrisy existing in the name of value system in our society.It questions the pseudo value system that people use to flaunt in our society. It deals with the dowry system that is deeply existing in the Indian middle-class mindsets that if a boy is highly educated, well settled, and earning a good package, he has a price in the name of dowry irrespective of how so ever the girl is educated and independent.

\section{Episode-5}

\section{"A marriage of convenience"}

Made in Heaven organizes a wedding in Ludhiana for an NRI groom who holds a contest to choose a local bride. Sukhmini Sadana the girl having a great American dream wins the contest which determines who will marry Jeet Gill, a wealthy NRI. Sukhmini believes that there is nothing in India, not even the good boys to get married, being over practical and over materialistic, she believes she knows how to rope in an NRI by talking about the Indian culture and values, finds out that the groom is impotent on their wedding night.Not being confident enough to face the society if she dissolves the marriage.She goes to USA with her husband.

"A marriage of convenience" questions running after the big American Dream. When Sukhmini finds out that Jeet is impotent Tara and Karan suggest that based on the impotency you can dissolve the wedding. Sukhmini replies that dissolve and divorce are the same in our Indian society and what will happen to me if I dissolve the marriage. So its better to go to America and find life there.

\section{Episode-6-}

\section{"Something Old Something New"}

Made In Heaven organizes the wedding of Gitanjali, a Wharton graduate banker with an NRI doctor Nikhil. An astrologer takes Gitanjali's parents into confidence that she is mangalik and get married to a tree firstly to avoid bad luck. Gitanjali 
agrees but Nikhil gets very angry, feels hurt comes to know about this. He argues with Gitanjali and she says this is just for the sake of our parent's happiness. Nikhil confronts by saying just think about our children and the values they will inculcate. Gitanjali makes Nikhil believe that she is agreed to him bit later she performs the tree marriage ceremony behind his back.

Something Old Something New" questions the superstitions that deeply exist in our Indian psychology that how so ever educated you are somewhere or the other you succumb under superstition. As at the end of the episode Kabir's monologue comes that -"Education can't cure everyone, Superstitions are there" sums up the whole episode.

\section{Episode-7}

\section{"A Royal Affair"}

Samar Ranavat a Rajput prince is getting married to a pilot Devyani Singh also from a royal family. A lavish celebration of progress and women empowerment is interrupted when a Mehendiwali (henna tattoo artist) is sexually assaulted by the groom's father. Tara and Karan try to get the girl justice but the girl is succumbed by the money offered to her by Devyani Singh.Devyani offers her 2 lakh rupees if she keeps her mouth shut but the girl asks for five lakh which Devyani agrees.

"A Royal Affair" talks about the Rich royal family class difference plays an important role in prevailing justice believing as everybody has a price. A Rich royal woman in pricing a poor girl's respect clearly showing the class difference. The henna artist who accepts money from the would-be daughter in law deconstructs her perspective to get something in return for what already has been done. She says with utmost innocence "I won't be able to ever earn this much money even by applying henna all my life", this explains how people succumb to social injustice when they know fighting is a tough ball game.

Later in this episode when Tara tells the whole story to Adil,he says that poor girl should have opted for 15 lakh rupees and she would get it as everybody has a price

\section{Episode-8}

\section{"Pride and Bridezilla"}

Tarana Ali is getting married and wants to make a music video.

Her father is suffering from debt, but that doesn't deter the girl at all. She just wants to shoot a marriage video. On the other side, the peon in Made in Heaven office is bailed out by Tara and Karan from taking a loan to fund his daughter's wedding by helping him with Rs 6 lakh. Rich or poor, there is nothing that is more important to a man's pride than getting his daughter married the way she wants.

"Pride and Bridezilla"-Every father goes through lots of pain to get his daughter married as a father he just wants to see his daughter happy on the wedding day. That feeling only deserves respect not the hype and hoopla behind the marriage. Every parent feels their daughter is a light who is going to light another house, keeping the dignity of these feelings. This episode questions the forced pressure to spend money on a daughter's wedding by the daughter herself.

\section{Episode-9}




\section{"The Great Escape"}

Uttar Pradesh's powerful political leader Brijesh Yadav's daughter Nutan Yadav is getting married to Vishal Singh. It is a wedding of political benefits as Vishal Singh is groomed to be the next Prime Minister. It's a marriage of political coalition against the Nutan's wishes and Nutan is constantly being drugged by her parents. Nutan loves a simple engineer named John an Engineer and wants to marry him. A simple engineer who is a Christian is absolutely against the political pride of Yadavs. Tara and Karan with the help of Kabir (Video person, Made in Heaven) find out about this and they meet John and helps Nutan elope with John just before the marriage. Nutan announces at a press conference her love for John and the news of their marriage in a church. She also shares with media that if something happens to us then her parents are to be held responsible. Nutan reveals the dark secret of her sister being killed by her family for loving a boy out of the community and the role of Yadav's in spreading the fake news of her suicide.

"The Great Escape" questions the big the powerful as how to fulfill the political ambitions they have no problem to kill their daughter's ambitions and dreams, not just that they can go to the extent to kill their daughter too without any qualms.are these kind people who lead the society will ever be able to respect the feelings of daughters?. The episode also questions the acceptance of love beyond caste, class, religion, and fame.

\section{METHODOLOGY}

For this study, researchers have extensively studied the content of Amazon Prime's web series Made in Heaven, Season 1. Each episode and central characters are analyzed in complete depth. The social stigma and cultural nuances prevalent in Indian culture are reflecting in weddings. The weddings planned by Made in Heaven are studied for a literature review to understand the context of the series in complete clarity. The character's insecurities, complexities, and relationships are discussed in detail for all the central characters. Also, a survey was conducted focusing on three aspects:

- The main storyline of the show

- Character complexities

- Character relationships

\section{Character's Journey Graph \& the Complexities}

\section{Tara and her Ambitions}

Tara is the glue that holds the whole together. She bites more than she can chew and then chews like hell. The situation of Tara is not all vanilla and marshmallow. Tara coming from lower-middle-class backgroundhails big dreams and ambitions. She doesn't like her family background. She marries Adil Khanna, asuper-rich and elitebusinessman. She roped him in through scandalous planning of attracting Adil and then releasing a tape online showcasing him in a compromising situation with Tara (See Episode7). There are continuous flashbacks of Tara dealing with her daunting past and efforts that she made to reach her aspirations. Tara is vulnerable, approval-seeking, manipulating yet so human to connect with viewers instantly.

\section{Karan and his Sexuality}

Karan discovers his sexual inclination in school towards men. Karan's character journey is showcased juxtaposed in flashbacks of his encounters with his love interest Nawab. His adolescence was a big denial of his orientation. Nawab wasn't but Karan was ashamed of his choices. This whole philosophy of straight orientation is reiterated by his mother through 
constant torture and pressure to succumb to straight sexual orientation. (See Episode 6)

The turning point in Karan's life is acceptance of his orientation that develops over a period with Nawab's memories. The guilt of hiding his sexual preference and pretentious behavior eventually help him overcome his fears. It also reveals in a way you realize why Karan has been so detached in his relationships and not wanted to deal with his homosexuality. He carries a certain burden of what happened to him when he was in his teens, just the fear of being caught. Just the fear of living a lie. The relief to Karan's long-time suffering ends with his acceptance of his reality.

After the jail experience, he is a bit of a damaged person. The agony to be not able to live freely in your own country. Karan and hislandlord Gupta's confession 'you are brave, you have courage', We waste our whole life hiding our reality.

\section{Adil and his Dichotomy}

Adil is a man of few words. He was gentle, polished, intellectual, and wise. The personality of Adil Khanna has shades of grey underlined with humane ideology. Adil cheats his ex-fiancé- Natasha, with getting involved with Tara, just before his marriage. After getting married to Tara, he cheats Tara, with her best friend Faiza (See Episode-2).He has a cheating bone in him, yet he doesn't come across as completely black. Viewers feel for him and connect to this human instinct that kind of blurs the boundaries of monogamy. Despite having an extramarital affair with their mutual best friend Faiza, he never disrespects Tara throughout. He is stuck between two females in his life. His wife Tara and best friend Faeza. Choosing one person and deciding to leave the other is a difficult choice for him. This is his dichotomy, that leads to a series of lies and deception in Adil's universe.

\section{Faeza and her Guilt}

A girl who was born with a silver spoon in her mouth and never even tries to earn a penny for her survival. Faeza is a rich businessmen's daughter and that is her only identity. She wears expensive clothes, carries a classy style, she paints but has no sense of independence. After she divorces her oppressing husband, (See Episode-3) Faeza gets involved with her best friend's husband and his childhood friend Adil.(See Episode-2) She lives in continuous guilt and is unapologetically involved with Adil. She secretly wants Adil to leave his wife(See Episode-3).This she confesses to a shrink as well.

\section{Jazz and her Exposure}

A girl hailing from congested lanes and ghettos. Jasmeet or Jazz, as she likes being called, is a girl with multiple shades. She is courageous, ambitious, emotional, and fearless. Jazz is the breadwinner of the family. She gets exposure and grooming through Made in heaven. (See Episode-2\&3). Jazz is too sorted for a girl of her age. She deals with her drug-addict brother and poverty stuck family with great charm and confidence (See Episode-5).

\section{Kabir and his Narration}

Kabir in his late twenties is a typical creative person. He is into filmmaking and stories are his passion. He captures all the weddings, Made in Heaven plans in his camera. His fresh style to tell all these tales behind marriages makes him unique. He is a thread that holds all the assignments of Made in Heaven weaved together. He is humane and confident. He doesn't step back in taking an extra effort to help people beyond the contract. (See episode 9) Kabir is fearless as he is not afraid to give a reality check to the bridezilla stuck spoilt girl.(See Episode- 8 )

\section{Characters Relationships \& the Narrative}




\section{Karan and Tara Relationship-}

Karan is at his vulnerable best only in front of Tara(See Episode 6). One hug sums up the relationship too beautifully where Karan says while coming out of the cell in jail that I am filthy, to which Tara replies 'I don't care'. Itis like feeling the heartbeat of the pain. For the first time, we see Tara worried for him and feeling that he would not recover from this trauma. The purest relationship in the entire series is the bond between Karan and Tara. They fight, share, respect, and rely on each other completely. The innate loyalty and trust are the foundation of this friendship.

\section{Adil and Tara}

The husband and wife share a complex relationship. He was charmed with her striving for unconditional love but in most cases it is conditional. It was a give and take sort of understanding. Tara gets a high-class lifestyle, a full-fledged established business founded by her Richie rich husband. Adil gets more than a trophy wife. Tara, after all, is independent and desirable. Though Adil is involved with Faeza, but not even once Adil thinks of leaving his wife (See Episode-3).Tara being aware of his relationship with Faeza keeps on trying to conceive a child and start a family ( See Episode-5).

\section{Tara and Faiza}

Faiza is a person who has groomed Tara for high society. (See Episode 2). The story goes into a flashback on Tara's wedding night where Tara is dressed as a bride both go to the washroom to smoke.Some girls comment on Tara to be a gold digger. Faeza rescues Tara with a prank. (See Episode-2).

WhenGayatri Mathurasked Tara to arrange Nobel Grapes for her wedding. Tara turns to Faeza for understanding the meaning of Nobel Grapes(See Episode-3).Tara invites Faiza to live in her husband's house after Faiza's divorces her husband. Later she gets the news of their affair. After Adil and Faiza's accident, Tara still gives blood to Faiza to save her life(See Episode-4).

\section{Tara and Family}

Tara doesn't share a great bond with her family. Her father is no more, she has a sister and a mother but doesn't share a very healthy relationship with either one. She is quite attached to her sister's daughter though, often gifts her expensive stuff (See Episode-3). Tara is childless and craves to have a family. At Adil's factory opening, Tara sees her mother and sister and is not very happy to see them. Mother tells, Adil has invited them. Tara's sister confronts Tara by saying ' that rotten place in your eyes is our home which used to belong to you' ( See Episode-2).

\section{Adil and Faiza}

Though Adil always has a soft corner for Tara and treats her with respect and love butfinds solace and class in Faiza's company and slowly Adil gets hooked with Faiza. The fact that both Adil and Faeza has a common thread, the background. This is a connecting link between them. Faeza is lonely and emotionally vulnerable, this makes her fall for her best friend's husband.Things start getting complicated when Adil and Faiza go on a road trip an met with an accident (See Episode 3) The affair gets out in the open yet Tara conceals the truth with families and pretends to move on.

\section{Karan and Nawab}

The story goes into a flashback, where Karan in his teens, discovers his sexual orientation with Nawab (See Episode-2). Karan in the whole journey is guilty of humiliating Nawab for homosexuality and hiding his orientation. Nawab is the driving 
force for Karan to accept himself and speak about his preferences openly to the world. Karan asks forgiveness from Nawab and reconciles their long time differences.(See Episode 9).

\section{Karan and Family}

Karan finds himself, a misfit in the family. It's a complex relationship with mother, father, and brother. Karan blames her mother for hiding his orientation. The brother is comfortable with Karan's life choices. At one point when the story goes into flashback where Karan has suffered a huge loss in business and is under huge debt, his mother forces his father to bail him out of debt (See Episode-3), whereas in episode 6 -Karan's father defends by facing themedia when Karan is jailed under Article 377, where homosexuality was a crime then.

\section{Kabir With Jazz}

Jazz Likes Kabir but, her aspirations are like Tara. She wants to get married to an extremely handsome man, hailing from an affluent background. Kabir is not a fit in her criteria. Jazz has an emotionally friendly relationship with Kabir (See Episode3). They care for each other and sometimes even have moments of comfort and closeness (See Episode-7). Kabir is protective of Jazz and admires her carefree and super cool nature (See Episode-8).

\section{Jazz and her Family}

Jazz comes from a Sikh family and the only earning member in the family. Her brother is extensively indulged in drugs, steals the jewelry that her mother has kept for Jazz's wedding (See Episode-4).Jazz is devastated but loves her family and brother. The fact that Jazz wants to change the economically ruined situation of her family is phenomenal and reflected in Jazz's personality throughout.

\section{The Questionnaire}

A survey was conducted with 100 sample size with the viewers of Made in Heaven, Season 1. The age group of the viewers is between 18-50. The questionnaire included questions based on the storyline of the show. The questionnaire focussed on the central characters, their relationships, and complexities. A five-point Likert scale was used to record the responses through an online survey.

\section{Analysis of Viewers Perspective: Made in Heaven, Season 1}

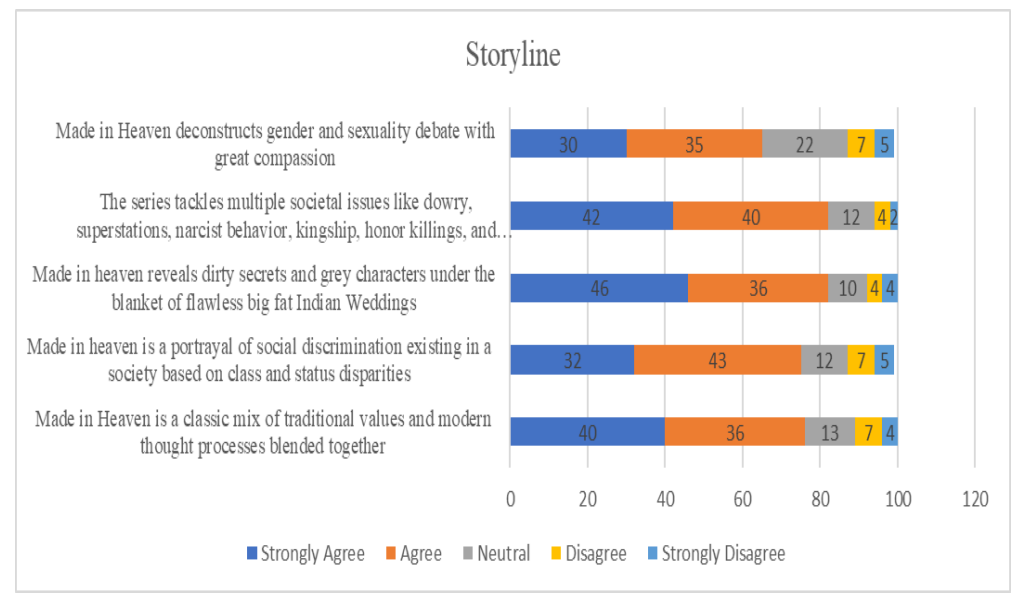




\section{Storyline- Findings \& Discussion}

The majority of viewers perceive made in heaven to be an apt portrayal of social and class conflicts persisting in Indian society. It reflects on cultural taboos and discrimination of all sorts existing in the deep ideologies of society. The show deconstructs myths, superstitions, and human thought processes in a creative format. The show is very engaging, and the narrative and storyline keep the viewer involved for all the nine episodes. The viewers are waiting for Season 2 and consider this so far, the best Amazon Original fictional Indian series based on relationships and class disparities.

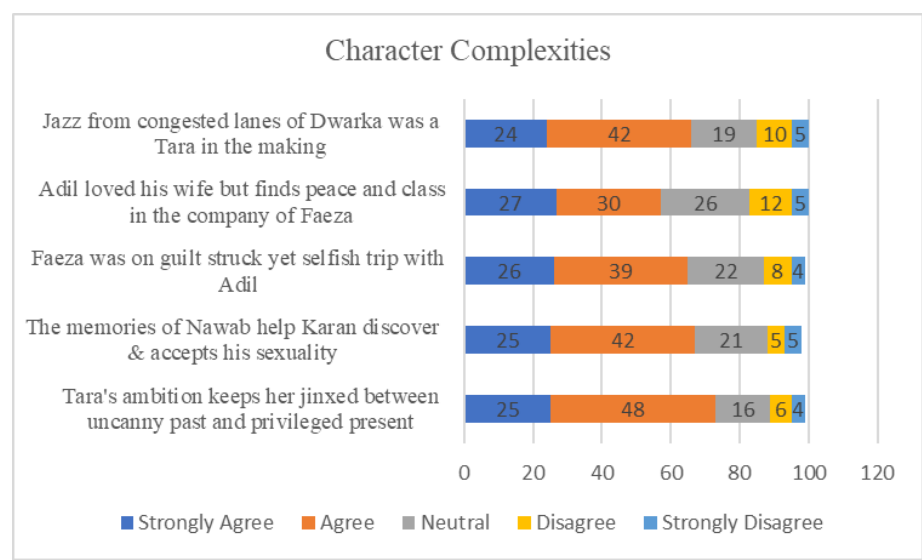

\section{Character Complexities- Findings \& Discussion}

Everyone is broken and twisted in their deep-down ideologies. There is no black and white in real life. An individual is somewhere in the spectrum of black and white.

- Viewers believe that Jazz is highly aspirational and unknowingly like the lead character Tara.

- Viewers feel Adil and his dichotomy hails from his upper-class mindset and Faeza is very much like him

- Viewers agree that Faeza is guilty of her actions but not much bothered about the consequences

- Viewers completely agree that Nawab is the torchbearer for Karan's realization about his sexual orientation

- Viewers feel that Tara is sandwiched between her past and present. Though she has achieved her dreams but has lost her identity in the process.

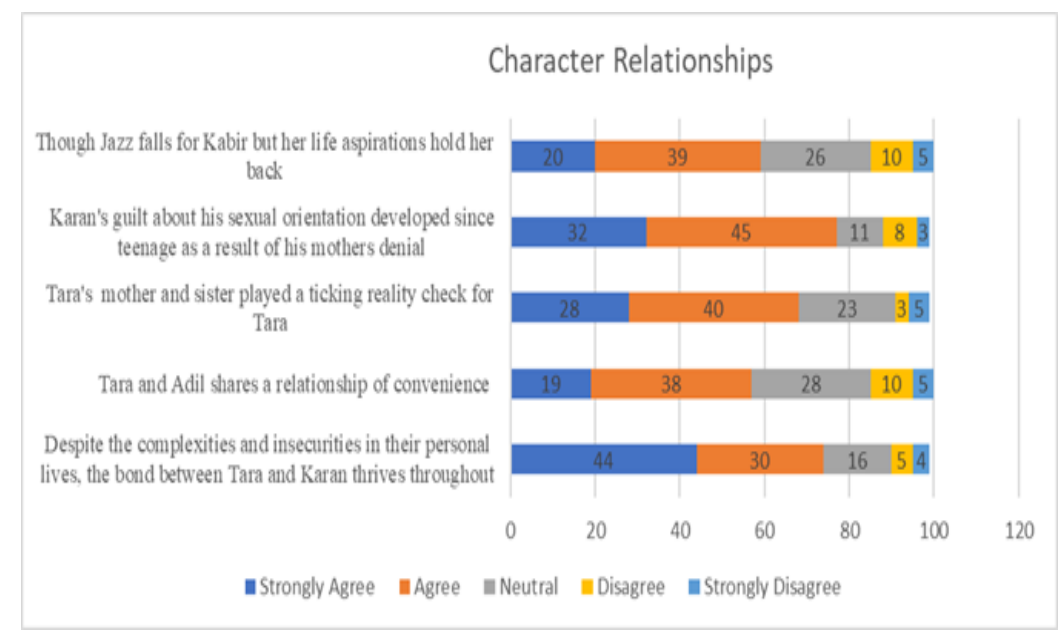




\section{Character Relationships- Findings \& Discussion}

The relationships are complex in Made in Heaven. The concept is much like real life. Everything is not hunky-dory and it takes efforts to mend this that are irreparable.

- Viewers perceive that Jazz is extremely sorted and is focussed on her aspirations. She has no time for relationships yielding no results.

- Viewers believe, Karan's denial about his sexual orientation hails from his family.

- Viewers also feel that Tara's family gave her a reality check time and then

- Viewers feel that Tara and Adil shares a superficial bond of convenience

- According to viewers the best relationship of the series, that triumphs throughout is between Tara and Karan, the two main protagonists and friends.

\section{CONCLUSIONS}

Amazon Prime's original web series Made in Heaven, Season 1, is a depiction of dark realities existing in the society. It has a very engaging central storyline based on two protagonists and their professional and personal journey in planning weddings in the upper-class society of New Delhi. The show highlights the personal insecurities of characters in a unique way. The characters have flawed relationships. They lie, manipulate, deceive, yet the graph of each character follows a progression with an unapologetic attitude. This is what majorly works for the show.

The realities and vulnerabilities of the characters are showcased very bravely by the writers and makers. No character is completely right or wrong. The shade of grey is attached to every character. Viewers have felt invested in the storyline because of the realistic nature of the series, powerful writing, and convincing acting of all the central characters.

The social and cultural taboos are handled with great compassion. Each episode in the series is addressing an issue existing in the society at all levels. From gold-digging to dowry transactions, the emptiness of single parents to class discrimination, molestation, virginity tests, powerstruggle, honor killing, superstitions to liability on a daughter's father to afford a fancy wedding, it has it all. The issue of homosexuality is dealt with great courage. Made in Heaven is a classic depiction of flawed relationships, realities of the supposedly liberal upper crust societies, and the inside stories to the superficial portrayal of a happy family.

\section{REFERENCES}

1. Barra, L. (2009). The mediation is the message Italian regionalization of US TV series as co-creational work. INTERNATIONAL journal of CULTURAL studies, 509-525.

2. Bucaria, C. (n.d.). Humour and other catastrophes: dealing with the translation of mixed-genre TV Series. Retrieved from file:///C:/Users/300559/Desktop/Paper\%20on\%20tv\%20series/series\%20refrence.pdf

3. Das, D. (2020). Web Series sensation in India: Endorsing women objectification through unrestricted online video streaming platforms. Studies in Indian Place Names.

4. Grover, P., \& Kadam, M. (2019). Web Series: The Impact of Age on the Time of Watching Web-Series (An Empirical Study of the Relationship between the Preference of Time to Watch Web Series and Age Factor). International Journal of Research in Engineering, IT, and Social Science. 
5. https://www.youtube.com/. (2019). Retrieved from YouTube: https://www.youtube.com/watch?v=uOUkDQaR5KQ

6. IMDb. (2019). Retrieved from https://www.imdb.com/: https://www.imdb.com/title/tt6494622/

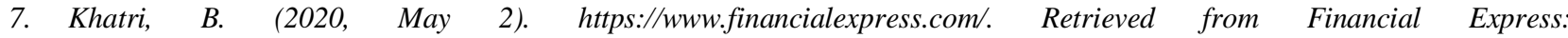
https://www.financialexpress.com/brandwagon/writers-alley/how-ott-platforms-are-leading-the-way-for-coming-of-age-ofprogrammatic-advertising/1946212/

8. Mark Hooper, A. M. (2010, September 27). Endurance Technology. Retrieved from http://www.endurancetech.co.uk/: http://www.endurancetech.co.uk/media/documents/OTT\%20TV\%20White\%20Paper\%202\%20version\%205\%20for\%20releas e.pdf

9. Moochhala, Q. (2018). The Future of Online OTT Entertainment Services in India. Lexipedia.

10. Singh, D. P. (2019). New Media as a Change Agent of Indian Television and Cinema: A study of over the top platforms. Journal of Content, Community \& Communication, Volume 9.

11. Tapswi, M., stiefelhagen, R., \& Bauml, M. (2015). “Knock! Knock! Whoisit?” ProbabilisticPersonIdentificationinTV-Series. ResearchGate.

12. Yıldırım, Y., \& Aydin, K. (2012). The Role of Popular TV Series and TV Series Characters in CreatingBrand Awareness. ResearchGate.

13. Goutam Bhatta, "Cloud Computing”, International Journal of Computer Science and Engineering (IJCSE), Vol. 5, Issue 3, pp.2016;

14. Krishnaveer Abhishek Challa, "Margaret Heffernan-A Business Woman Versus A Writer", BEST: International Journal of Humanities, Arts, Medicine and Sciences (BEST: IJHAMS), Vol. 4, Issue 1, pp. 1-4

15. Shorunke Muyiwa Musaddiq, "Towards Securing Data in the Cloud”, IMPACT: International Journal of Research in Applied, Natural and Social Sciences (IMPACT: IJRANSS), Vol. 2, Issue 4, pp. 123-126

16. Shraddha Kulkarni, "Inclusion of Corporate Social Responsibility Practices as a Part of Curriculum @ Indira School of Business Studies, India and its Impact Over the Awareness \& Sense of Responsibility of Students towards Community", International Journal of Business and General Management (IJBGM), Vol. 6, Issue 3,pp. 1-18 